\title{
The Influence of Interval Exercise Method on Swimming Speed of 50 Meters of Chest Style
}

\author{
Rihan Salmon Aziz ${ }^{1}$ and Roma Irawan ${ }^{2 *}$ \\ 1,2Dep. of Coaching, Faculty of Sport Science, Universitas Negeri Padang, Padang, Indonesia \\ *Corresponding author. Email: romairawan@fik.unp.ac.id
}

\begin{abstract}
The problem in this study is the ability to swim the speed of swimming students who study basic swimming, Department of Coaching. Faculty of Sport Science. Padang State University. The purpose of this study was to determine the effect of interval training methods on swimming speed of 50 meters breaststroke on students who take basic swimming courses, Department of Coaching. The population in this study were students who studied basic swimming, the number of samples in this study were 10 people who were filtered using cluster sampling (area sampling). This type of research used an experimental method. Data were collected through a 50 meter breaststroke swimming speed test. Then analyzed using t test statistics. Based on the test results of the 50 meter breaststroke swimming speed variable, the calculated value or $T_{-}$count $=53.45>T \_$table $=1.833$ and there was an increase in the $50 \mathrm{~m}$ breaststroke swimming speed. So it can be concluded that the 50 meter interval training for breaststroke has a significant effect on increasing the speed of students in basic swimming lectures, Department of Coaching. Keywords: Interval Training, Speed, and Swimming Breaststroke.
\end{abstract}

Keywords: Interval exercise method, swimming speed

\section{INTRODUCTION}

Adi Padang Club is one of the Bolavoli clubs which takes place in training at the H. Agus Salim sports hall in Padang City. Until now Padang Adios is still actively conducting achievement training for athletes. In an effort to develop and improve athletes' achievements, the board sets a training schedule six times a week that is supported by adequate training facilities and infrastructure.From some playing techniques in the Bolavoli game, service technique is one technique to score points in a match. The main objective of the service technique in the Bolavoli game is to start the match and also aim to snap (collect) points. Every time a service ball that cannot be returned or the ball hits the ground on the opponent's playing field, that service can produce a point for the service team.

When the researcher observed directly when the Bolavoli club player Padang Adios was playing, a lot of points were gained by the opponent due to mistakes from the Bolavoli player Padang Adios club itself. Like when a player serves, the services that are done are often off the playing field by several players, the services are often involved on the net by several players, the service ball movement looks slow, so the ball is easily returned by opponents, most players serve in a monotonous direction to the opponent's playing field.
From the problems that occur it can be understood that the service ability of the Bolavoli club Padang Adios players can be said to be still low and needs to be improved.

Based on the experience of researchers during the training internship at the Padang Adios club that trainers tend to provide monotonous forms and methods of training. Monotonous exercise results in the athlete's boredom in training. The aftermath of an athlete's boredom makes the athlete's enthusiasm and motivation decrease during the training process and results in the training goals being unable to be achieved effectively and efficiently. Therefore, the forms of service technique training need to be modified in the form of games. It aims to foster a sense of excitement, excitement, and enjoy so that players have a high training spirit.

Basically, the principle of playing form modification is to realize the exercise of top service techniques in the form of games, both in groups and individually. The main purpose of this modification is to foster joy, pleasure, excitement, and enthusiasm so that players can participate in each training session without being overburdened and fed up. If this can be done then the purpose of the top service training can be achieved effectively and efficiently.

Based on the problems related to the low service ability of Bolavoli club Padang Adios players, the 
researchers were interested in treating the players through a study. The research that the researcher will do is to apply the modified form of play in the process of training the top servisgram techniques. The expected goal of this treatment is to improve the ability of the service techniques of Bolavoli club players, Padang Adios.

According to Yunus in Riyadi Slamet, (2012) states that: "Bolavoli game is a sport game played by two squads on a rectangular field separated by the net, the purpose and purpose of this game is to put the ball into the opponent's area through an obstacle in the form of a rope or net and try to win the game by turning off the ball in the opponent's area. "Meanwhile, according to Muhajir in Sari \& G. Guntur, (2017) argues that: "Basically the principle of playing Bolavoli is to bounce the ball before it touches the floor, the ball is played three times reflecting on its own field alternately by working the bounced ball across the field. the opponent passes over the net and is tried to accept the opponent as difficult as possible. "

Based on the opinions on the previous page, the Bolavoli game is a game that aims to build attacks and defend their own area from the opponent's attack or defend their own area from dead balls. To achieve this requires basic techniques in good Bolavoli games. According to Beutelstahl in Irwanto, (2017) explained that, the basic technique of Bolavoli is an important factor that must be considered in Bolavoli playing skills, with good and correct techniques that will have an impact on productivity and effectiveness in playing Bolavoli ". The techniques in the Bolavoli game consist of service, bottom passing, top passing, block, and smash. Specifically for basic service techniques, the service techniques in Bolavoli are broadly divided into lower and upper service techniques.

Opinion Syaleh, (2007) "Top service is a type of service that makes the ball not contain rotation (the ball moves to float or float)". Yusmar's opinion, (2017) 'one of the techniques in volleyball is service. A serve is a punch or serving of the ball as a first strike to the opponent's area as a sign of a game. "Based on the opinion referred to, it can be concluded that service is the first blow taken by a player (server) to the opponent's area as a sign of the start of a game. Service is performed by a right-most player performed in the service area. Therefore, service in the game Bolavoli is a basic technique that has an important role in the course of a match.

The tactics of servicing above according to Ika Noerjannah, (2016) are a) directing service to opponents who are passing through; b) point the service to an empty area; c) direct the service to the back corner area so that it is difficult for the opponent to aim at the feeder; d) direct the service to new players who just made a mistake; e) direct the service to players who have just entered as substitutes.One common problem that often arises in the ongoing training process is that one is bored (bored) from athletes, and Bolavoli is no exception. Monotonous training tends to trigger an athlete's boredom. The feeling of boredom has a psychological impact on athletes such as decreased enthusiasm for training. If this happens in the process of training the top service techniques then the aim to improve the ability to service will not be achieved effectively and efficiently.

Based on this, one of the ways that can be done to overcome the boredom (boredom) of athletes is to modify the service technique exercises in the form of play. "Modification is generally defined as an effort to change or adjust. However, the modification specifically means the efforts made to create and display something new, unique and interesting. Modification here refers to a creation, adjustment, a tool or infrastructure that is new and unique (Saputra, 2015) ". "Modification is analyzing as well as developing a form and directing the parties contained in it to make from what can not be able, from low level to higher, and who were less skilled to become skilled (Lutfi, 2013)".

So, what is meant by modification is an attempt made to change or adjust a thing from the initial concept according to the needs, so that the change or adjustment creates a new, unique, and interesting thing. Related to this research variable, the intended modification is modification of top service exercises into play.But before discussing the modification of play the first few definitions of play are put forward. Saputra, (2015) "Playing is a fun activity and through physical, mental, and emotional aspects". Sukintaka in Wijaya (2013) "What is meant by play is an activity that is loved by children".

So play modification is an effort made to change or adjust the form of service training on the original concept into a game according to the needs, so that the changes or adjustments create the forms of top service training in the form of play so as to create an atmosphere of service training on an interesting, enjoyable, and uplifting. The purpose of modification according to Aussie in Lutfi, (2013) "Modified sports foster joy and pleasure in children in competitive situations". Lutan in Zalfendi, (2010) "The purpose of modification is: a) Obtaining satisfaction in training, b) Increase the likelihood of success in participating, c) Children can move correctly ".Based on this theory, it can be understood several objectives of modifying the form of play in carrying out the training process, including: Able to overcome boredom in athletes (children), training activities can run without pressure so 
that the exercise runs with excitement, fun, and gain satisfaction, strengthen social relations between athletes (children), increasing the likelihood of success in participating. Victorian Branch in Akhbar, (2013) said: "Game models emphasize the application of skill strategies and manipulation of game rules to develop mindsets and decision making for action. The game focuses on techniques (skills), to encourage someone to do tactics and act to get better results during the game ".

The expected achievement of the modified form of play is how the training objectives can be achieved effectively and efficiently with a pleasant training process. As Piaget argues in Arniza, (2016) "Games as a medium that enhance children's cognitive development. Games allow children to practice the competencies and skills needed in a relaxed and fun way. "the thing to do to make modifications is to modify the important components of the exercise to be done. According to Aussie in Arniza, (2016) "important components that can be modified include: 1) the size of the weight or shape of the equipment used, 2) the playing field, 3) the short playing time, 4) the rules of the game, 5) the number of players". For example a form of service training with a modified form of play is to service by placing stacking boxes in the plot area as a service target. The server tried to hit and tear down the arrangement of the boxes. An example of this form of exercise aims to improve the ability of the server in terms of placing the ball (service accuracy).

\section{RESEARCH METHODS}

This research is a type of quasi-experimental research (Quasi Experiment) using the experimental design of one group pretest-posttest design (Suryabrata, 2010). The study was conducted at the Padang Adios club in West Sumatra. The population in this study amounted to 19 people (10 male athletes and 9 female athletes) Padang Adios volleyball club. Furthermore the study sample numbered 19 people (10 male athletes and 9 female athletes) with a sampling technique that is saturated sampling (Sugiyono, 2009). The independent variable in this study is the modification of the form of play, while the dependent variable is the service ability of volleyball.

Data collection techniques were performed on samples using a service capability test from AAHPERD, (Winarno, 2006). The data analysis technique used was to use the t-test formula (bedamean test). To meet the assumptions requirements the normality test was intended to determine the data obtained whether or not normal distribution and homogeneity test with the F test, aims to determine whether the data are homogeneous or heterogeneous.

1. Data on Service Capability of Men's Club Bolavoli Padang Adios

Based on the analysis of preliminary test data on the service ability of male players, the following data distribution is obtained: High point $=17$ and low pointer $=7$, mean points $=12.60$ and standard deviation $=3.20$. Then based on the analysis of the final test data on service ability of male players, the following data distribution is obtained: High point $=18$ and low pointer $=9$, mean points $=14.70$ and standard deviation $=2.98$. The following can be seen in the histogram below.

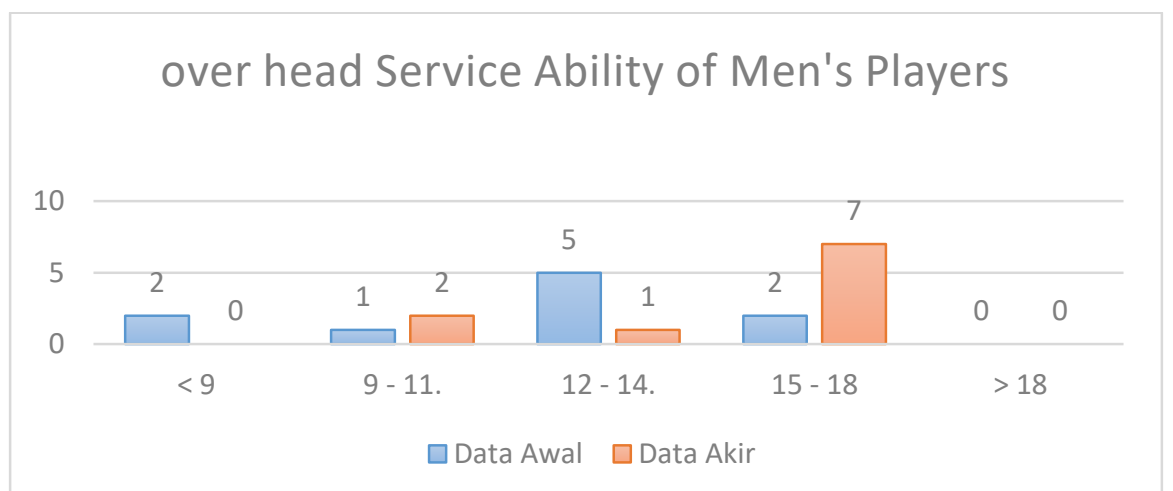

Figure 1. Histogram of Initial Test Data and Final Test Data for Service Capability of the Putra Club Club in Padang Adios Club

Based on the data contained in the image of the stem histogram, the explanation can be given as follows. For preliminary test data from 10 people, 2 people $(20 \%)$ have a level of service ability for volleyball with points ranging between $15-18$ points. 5 people $(50 \%)$ have a level of service ability for volleyball with points ranging from $14-12$ points. 1 person $(10 \%)$ has a level of service ability for volleyball with points in the range of $9-11$ points. 2 people $(20 \%)$ have a level of service ability for volleyball with a small point gain of 9 points. 
Furthermore, for the final test data on top service ability, out of 10 people, as many as 7 people $(10 \%)$ have a level of service ability on volleyball with points ranging between $15-18$ points. 1 person $(10 \%)$ has a level of service ability for volleyball with points ranging from 14 - 12 points. 2 people (20\%) have a level of service ability for volleyball with points ranging from 9-11 points.

2. Data on Service Capability of Bolavoli Women's Club Players Padang Adios
Based on the analysis of preliminary test data on the service ability of female players, the following data distribution is obtained: High point $=18$ and low pointer $=3$, mean points $=9.78$ and standard deviation $=5.09$. Then based on the analysis of the final data of the service capabilities of the female players the data distribution is obtained as follows: High point $=19$ and low pointer $=7$, mean points $=11.78$ and standard deviation $=3.83$. The following can be seen in the histogram

image.

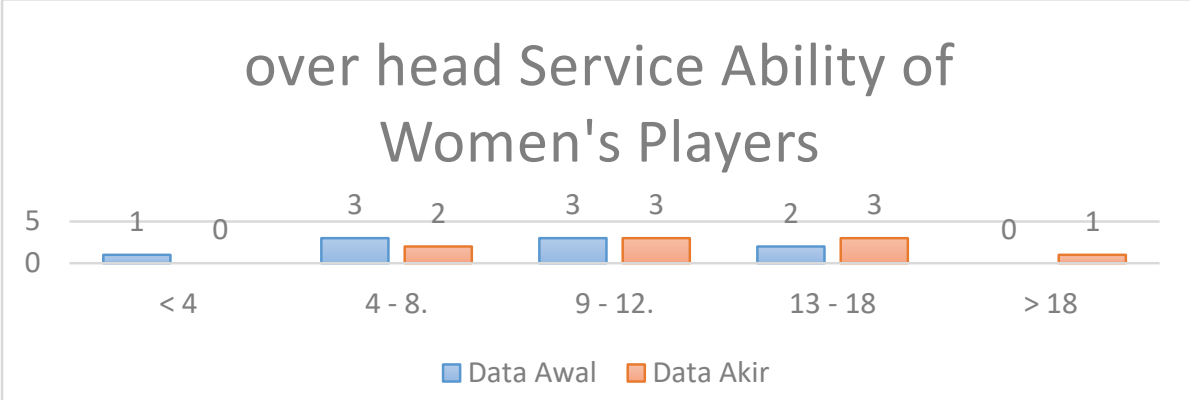

Figure 2. Histogram of Initial Test Data and Final Test Data on Service Capability of Putri Club Club Player in Padang Adios

Based on the data contained in the image of the stem histogram, the explanation can be given as follows. For the initial test data from 9 people, 2 people $(22.2 \%)$ have a level of service ability for volleyball with points ranging between $13-18$ points. 3 people $(33.3 \%)$ have a level of service ability for volleyball with points ranging from 9-12 points. 3 people $(33.3 \%)$ have a level of service ability for volleyball with points ranging from 4 - 8 points. 1 person $(11.1 \%)$ has a level of service ability for volleyball with a small point gain of 4 points.

Furthermore, for the final test data on top service ability, from 9 people, as many as 1 person $(11.1 \%)$ has a level of service ability for volleyball with a gain of 18 points. 3 people $(33.3 \%)$ have a level of service ability for volleyball with points ranging from $13-18$ points. 3 people $(33.3 \%)$ have a level of service ability for volleyball with points ranging from 9-12 points. 2 people $(22.2 \%)$ have a level of service ability for volleyball with points ranging from $4-8$ points.

a. Data Normality Test

Data normality test is done by using the test of relief with a significance level $\alpha=0.05$. The following can be seen summarizing the results of data normality test analysis in the following table.

Table 1. Summary of Data Normality Test Results

\begin{tabular}{|l|l|l|l|l|}
\hline Varibel & $\mathbf{n}$ & $\mathbf{L}_{\mathbf{o}}$ & $\mathbf{L}_{\mathbf{t}}$ & Information \\
\hline Pre Test (Men) & 10 & 0,130 & 0,258 & Normal \\
\hline Post Test (Men) & 10 & 0,143 & 0,258 & Normal \\
\hline Pre Test (Women) & 9 & 0,153 & 0,271 & Normal \\
\hline Post Test (Women) & 9 & 0,135 & 0,271 & Normal \\
\hline
\end{tabular}

Based on the summary table, it can be explained as follows. The results of normality test data for the initial data of the service ability of male players obtained Lo score $=0.130$. With $\mathrm{n}=10$, and $\mathrm{a}$ significant test level $\alpha=0.05$, then obtained $\mathrm{Lt}=0.258$ greater than $\mathrm{Lo}$, so $(\mathrm{Lo}=0.130<\mathrm{Lt}=0.258)$. Then for the final datates the service ability of male players is obtained Lo score $=0.143$. With $\mathrm{n}=10$, and a significant test level $\alpha=0.05, \mathrm{Lt}=0.258$ is obtained greater than Lo, so $(\mathrm{Lo}=0.143<\mathrm{Lt}=0.258)$. Thus it can be concluded that the preliminary test data and the final test of service ability for male players come from populations that are normally distributed.Then the results of normality test data for the initial test of service ability for female players obtained Lo scores $=0.153$. With $\mathrm{n}=9$, and a significant test level $\alpha=0.05, \mathrm{Lt}=$ 0.271 is obtained greater than Lo, so $(\mathrm{Lo}=0.153<\mathrm{Lt}=$ $0.271)$. For the final data on the service ability of the female players, a Lo $=0.135$ score is obtained with $\mathrm{n}=$ 9 , and a significant test level $\alpha=0.05, \mathrm{a} \mathrm{Lt}=0.271$ is greater than Lo, so $(\mathrm{Lo}=0.135<\mathrm{Lt}=0.271)$. Thus it can be concluded that the initial test data and the final test data on the ability to service for female players come from populations that are normally distributed. 


\section{b. Homogeneity Test}

Homogeneity test $\mathrm{s}$ carried out aimed at determining whether the variance of each data (male data and female data) includes homogeneous or heterogeneous data groups. Homogeneity test data is done by the $\mathrm{F}$ test.By using the degrees of freedom (n1$1),(\mathrm{n} 2-1)=(10-1),(10-1)=(9.9)$ and the significance level $(\alpha)=0.05$ in the $F$ distribution table reads the significance limit $(\mathrm{Ft})$ is 3.18 , it can be seen in Appendix 12 page 151. Considering that the Fh value is smaller than the Ftmaka price, it can be concluded that the two variances of the data are homogeneous. In other words it can be concluded that the two groups of data (initial test data and final test data) come from a homogeneous population.

By using the degrees of freedom $(\mathrm{n} 1-1),(\mathrm{n} 2-1)=$ $(9-1),(9-1)=(8.8)$ and the significance level $(\alpha)=0.05$ on the $\mathrm{F}$ distribution table reads the significance limit (Ft) is 3.41, it can be seen in Appendix 13 page 152 . Considering that the Fh value is smaller than the Ftmaka price, it can be concluded that the two variances of the data are homogeneous. In other words it can be concluded that the two groups of data (initial test data and final test data) come from a homogeneous population.

Based on the results of the t test analysis, it was obtained $\mathrm{th}=8.14>\mathrm{tt}=1.83$ (for data serviceability for male players) and th $=3.46>\mathrm{tt}=1.86$ (for data serviceability for female players) with significance level $\alpha=0.05$. Thus, the research hypothesis is accepted as a real truth. The conclusion is that there is a significant influence of modification on the form of play on improving the service ability of Bolavoli club player Padang Adios.From the observations of researchers during the research process, the researcher believes that one of the factors that causes the modification of play can improve the ability to service is motivation. The high motivation of players to follow the training process makes the players can run the exercise effectively and efficiently. Sardiman's Opinion, (2014) "Motivation is defined as an effort to encourage someone to do something. Motivation is the driving force that has become active ".

In an effort to have good service skills, it is not enough just to master or improve the technique through modifying the form of play. This is because that the ability of the service technique is influenced by many factors, including physical condition. To hit the ball hard and fast, special physical conditions are required, including explosive power in the arm muscles. According to Siregar, (2015) explosive power is the ability of muscles to exert / exert maximum strength in a very short time. The same thing was said by
Sukadiyanto in Pujo, (2015) explosive power is the product of strength and speed.

Athletes who have good arm muscle explosive power, it will produce good top service ability too, because serving in the game of volleyball in addition to aiming to start the beginning of a game (first hit) also aims to get points or points. If service cannot be returned by the opposing team, the service team will get one point or point.

\section{CONCLUSIONS AND SUGGESTIONS}

Based on the results of data analysis, the following conclusions can be obtained: There is a significant modification of the playing form on the service ability of Bolavoli Club Padang Adios players. the application of playing form modifications in the training process can improve the service ability of volleyball.

\section{REFERENCES}

[1] Akhbar, M. Taheri. 2013. The Effect of Playing Series Method, Training Series, and Intstrumental Aggressiveness on Football Playing Skills. Thesis (unpublished). Padang: Postgraduate UNP.

[2] Arniza, Alfinosia. 2016. The Effect of Elementary Method and Game Modification Method on the Skill of Playing Football SSB Talang Babungo, Hiliran Gumanti District, Solok Regency. Thesis (unpublished). Padang: Postgraduate UNP.

[3] Irwanto, Edi. 2017. "The Effect of Reciprocal Methods and Drill Exercises on Enhancing Basic Volleyball Technical Skills". Journal of Physical Education. Vol 6. No 1, June. Pages 10-20.

[4] Lutfi, Achmad. 2013. Penjasorkes Learning Through Modification of Mini Volleyball Game For Class V Students of Susukan State Elementary School 01 District of Ungaran Timur, Semarang Regency. Thesis. (Not published). Semarang: Faculty of Sport Science, Semarang State University.

[5] Noerjannah, Ika. 2016. "Concentration Contribution to Service Accuracy Skills for Volleyball in Female Players SMK Negeri 1 Kemlagi Mojokerto". Journal of Sports Health. Vol 05. No. 2, July. Pp. 47-50.

[6] Pujo, Danang Broto. 2015. "The Effect of Pliometrics Exercise on the Muscle Power of the Volleyball Youth Athletes". Journal of Motion. Vol VI. No. 2. Pages 174-185.

[7] Riyadi, Slamet. 2012. "The Effect of Training Differences on the Ability of Volleyball Smash". Journal of Sport Science. Vol 01. No 01. Pages 31 38.

[8] Saputra, Iwan. 2015. Modification of Learning Media for Elementary School Physical Education. Unimed Journal, Volume 14 number 2, July- 
December 2015: 35-41.

(Https://jurnal.unimed.ac.id).

[9] Sari, Yohana Bela Christian and G, Guntur. 2017. "The Effect of Training Methods and Eye-Hand Coordination on Service Skills for Volleyball". Sports Journal. Vol 5. No. 1 January. ISSN 23390662. Pages 100-110.

[10] Siregar, Irwansyah. 2015. "Relationship between Arm Muscle Power and Back Muscle Flexibility Against the Ability of Sercice in Volleyball Games". Journal of Community Service. Vol 21. No 79. Pg. 45-49.

[11] Sugiyono 2009. Educational Research Methods Quantitative, Qualitative, and R\&D Approaches. Bandung: Alfabeta.

[12] Suryabrata, Sumadi. 2010. Research Methodology. Jakarta: PT Raja Grafindo Persada.

[13] Syaleh, Muhammad. 2007. Efforts to Improve Learning Outcomes of Service for Volleyball Through Paper Ball Throwing Learning Media for Class VII Middle School Students. Journal of Achievement Vol. 1 No. 1, June 2017: 23-30 (https://jurnal.unimed.ac.id)

[14] Wijaya, Betra Sendra. 2013. The Effect of Playing Methods on Increasing the Lower Passing of Volleyball Extracurricular Participants in SMA Negeri 1 Bantul. Thesis (Not Published). Yogyakarta: Faculty of Sport Science, Yogyakarta State University.

[15] Winarno. 2011. Research Methodology in Physical Education. Malang: Media Main Horizon Press

[16] Yusmar, Ali. 2017. "Efforts to Improve Volleyball Game Techniques Through Game Modification of Class X Students of SMA Negeri 2 Kampar". Journal of Education and Teaching Primary School Teacher Education Study Program FKIP Riau University. Vol 1. No 1 July. ISSN 2580-8435. Pp. 143-152.

[17] Zalfendi, et al. 2010. Learning Strategies. Padang: UNP Press. 